\title{
On the Function of Piriformis Muscle in Relation to Piriformis Syndrome
}

\author{
Umut Serkan Söztanacı, Seren Kaya and Hüseyin Avni Balcıoğlu* \\ Department of Anatomy, Faculty of Medicine, University of Health Sciences, Istanbul, Turkey \\ *Corresponding author: Hüseyin Avni Balcioğlu, Prof. of Anatomy, Department Head. Department of Anatomy, Faculty of \\ Medicine, University of Health Sciences, Istanbul, Turkey. E-mail: h.avni@sbu.edu.tr
}

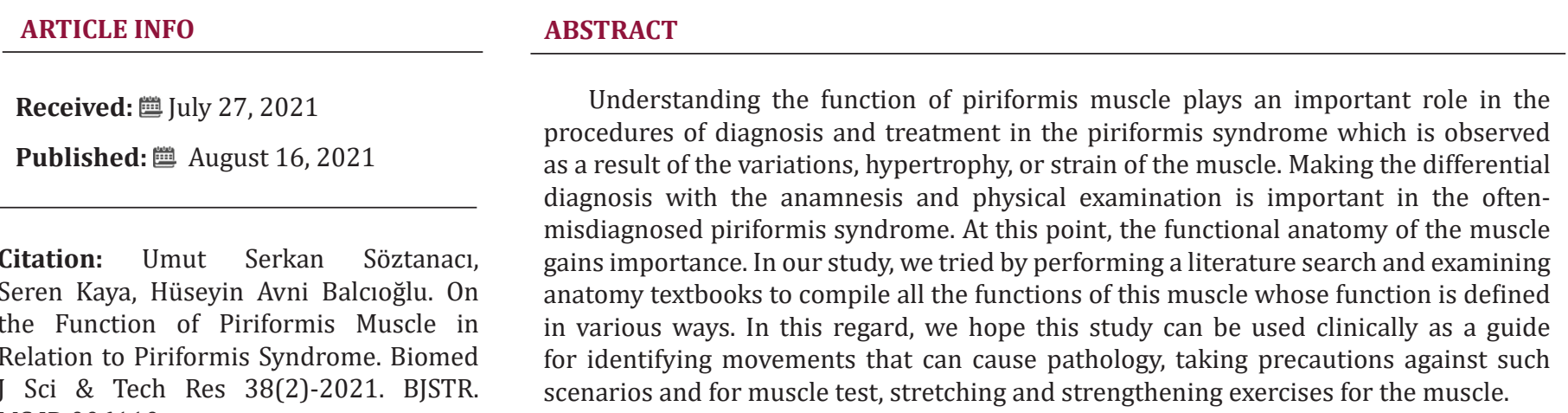
MS.ID.006110.

Keywords: Piriformis Muscle; Piriformis Syndrome; Clinical Anatomy

\section{Introduction}

Piriformis is the largest muscle among the deep short external rotators of the hip and a functionally important muscle which attaches two joints, sacroiliac, and hip joints [1,2]. In clinic, the pathologies that occur in this muscle which has important neurovascular adjacencies in gluteal area cause piriformis syndrome characterized with hip and waist pain in sitting position or during hip movement [2-4]. While this rarely seen syndrome can easily be diagnosed via anamnesis or physical examination, it is often misdiagnosed as lumbar discopathy. Piriformis syndrome should be considered in differential diagnosis of non-discogenic sciatalgia $[3,5]$. In literature, it is observed that piriformis muscle is discussed superficially, which, in fact, must be clinically welldefined and has many functions. Therefore, in our study, we tried to compile all functions of the muscle in literature, with the hope of it becoming a guide in clinical diagnose and treatment.

\section{Topographic and Clinical Anatomy of Piriformis Muscle}

Starting from the S2-S4 level of the pelvic surface of the sacrum, the gluteal surface of the ilium that is close to the posterior inferior iliac spine, the sacroiliac joint capsule, Sacro tuberous ligament, exiting pelvis, it advances through lateral by dividing greater saciatic foramen in two to form suprapiriform and infrapiriform foramen $[2,6,7]$. It terminates in femur, in the medial of upper side of greater trochanter. Its tendone often merges with gluteus medius muscle tendone, either in conjunction with gemelli muscles and obturator internus muscle joint tendone or by itself [2]. Important neurovascular structures pass through infrapiriform foramen, including sciatic nerve [2]. In literature, case examples with variations of no or two piriformis have been reported [8-11]. There are also variations of sciatic nerve dividing into branches and variations of their adjacency with piriformis. Sciatic nerve or one of its branches is observed to pass through the muscle in $7-21 \%$ of the examined poplutaions.

This adjacency causes nerve compression and results in piriformis syndrome [4,12,13]. Apart from these anatomical variations, piriformis syndrome may occur due to a sudden, powerful internal rotation which may cause chronical weak body mechanics, hypertrophy and myofascial trigger point syndrome 
caused by excessive use of the muscle, and acute muscle strain. These factors cause sciatica pain caused by irritations of sciatic nerve which approaches piriformis muscle during hip movements $[4,5]$. Stretching exercises, dry needling, kinesiological taping, soft tissue massage techniques are often used to reduce nerve compression and to achieve symptomatic relief in treatment [13, 14]. The function of the muscle must be clearly comprehended for the best treatment.

\section{Functional Anatomy}

The main function of piriformis, one of the short external rotator muscles of femur, is to provide external rotation while femur is in extension and its secondary function is to provide abduction while femur is in flexion [15-17,2]. The abduction of femur prevents falling by transferring bodyweight to the related side during the stance phase of walking [16]. Piriformis muscle might also help starting the hip extension $[15,17,18,19]$. In one study, the percentage torque according to total hip torque of piriformis muscle in each axis was calculated and found to cause 35\% extension, 56\% abduction, $75 \%$ external rotation relatively [19]. An electromyography study found that the maximum activation of piriformis muscle was during resistive hip extension. The maximum activation in eccentric phase was observed during single leg bridge exercise. The other exercises that cause high muscle activation in the study are heel squeezing in the prone position and abduction moves while leg is in external rotation in side-lying position. The high activation of muscle during moves like exercises such as single leg bridge, heel squeezing in the prone position that cause static external rotation ensures hip stabilization and prevents internal rotation [20]. Increased piriformis strength was observed in addition to hip external rotation increase by wight transfer while climbing down a ladder in patients with pre- and post-operative femoral acetabular impingement syndrome, compared to healthy individuals [21]. In the flexion of the hip over $70^{\circ}-90^{\circ}$, piriformis muscle creates internal rotation torque in horizontal plane and its function is observed to change $[17,19,22]$.

It is reported that preventing rotation helps the abduction of femur and that femur acts as a hip abductor in $90^{\circ}$ flexion and as an internal rotator in above $110^{\circ}$ flexion [18]. This internal rotation occurs in pathophysiology of knee-bent walking observed in cerebral palsy [22]. It also tilts pelvis down laterally and posteriorly by pulling the sacrum downward toward the thigh [15]. While sacrum is stable, piriformis muscle brings femur to external rotation, abduction, and flexion, and while femur is stable, it brings pelvis to extension with bilateral contraction and causes pelvis to do internal rotation with unilateral contraction $[23,24]$. While hip goes from external rotation to internal rotation in the stance phase of walking, piriformis muscle extends and then stretches with lateral tilt of pelvis. It is thought to be a stretch reflex resulting in contraction followed by a second contraction in swing phaseto help external rotation. Because piriformis shows two contractions, it is observed to be liable to hypertrophy [25]. In a study which compares walking at different slopes, more power was observed to emerge in piriformis at high slope than at low slope [26]. Piriformis, with other extensor rotator muscles, pull femur at different angles and act as a functional muscle. These muscles are regarded as cuff muscles of the hip and helps stabilize the head of femur at acetebulum [18,23,24,27]. These muscles have an importance as postural muscles rather than creating power by providing pelvis with control over stable femur [27].

Table 1: Function of piriformis muscle according to anatomy textbooks.

\begin{tabular}{|c|c|}
\hline The name of the textbook & Function of piriformis muscle \\
\hline BRS Gross Anatomy [28] & Supination to femur \\
\hline $\begin{array}{c}\text { Resimli Sistematik Anatomi } \\
\text { (Turkish) [7] }\end{array}$ & $\begin{array}{c}\text { Abduction and lateral rotation to } \\
\text { femur }\end{array}$ \\
\hline Ozan Anatomi (Turkish) [29] & $\begin{array}{c}\text { External rotation to femur, } \\
\text { abduction to femur in flexion }\end{array}$ \\
\hline $\begin{array}{c}\text { Gray's Anatomy, The Anatomical } \\
\text { Basis of Clinical Practise [2] }\end{array}$ & $\begin{array}{c}\text { Lateral rotation of femur in } \\
\text { extention and abduction in flexion }\end{array}$ \\
\hline Clinically Oriented Anatomy [6] & $\begin{array}{c}\text { Lateral rotation and abduction to } \\
\text { femur; keeping femur's head in } \\
\text { acetebulum }\end{array}$ \\
\hline Clinical Anatomy by Regions [30] & $\begin{array}{c}\text { lateral rotation to femur in hip } \\
\text { joint }\end{array}$ \\
\hline Netter's Clinical Anatomy [31] & $\begin{array}{c}\text { lateral rotation to femur in } \\
\text { extension; felxion to femur in } \\
\text { flexion; stabilization of hip joint }\end{array}$ \\
\hline
\end{tabular}

It helps stabilize the joint by preventing femur's internal rotation during walking [18]. Piriformis muscle has a secondary function in stabilizing this joint with iliopsoas muscle, by clinging to sacroiliac joint capsule or its boundaries [22]. It is also regarded as a powerful stabilizer of sacroiliac joint [18]. It helps sacroiliac joint's stabilization while femur is stable in situations such as lifting weight, stance phase of walking [1]. Piriformis muscle provides balance between sacrum- ilium, sacrum- vertebra by creating anteroposterior movement of sacrum. Iliopsoas muscle provides balance between hip, pelvis, and lumbar vertebra by clinging to lesser trochanter in the anterior. With obturator muscles joining these muscles, they create a web and help thorax, lumbar vertebra, pelvis, sacrum connect to lower extremity [27]. While various functions of piriformis muscle are defined in literature, its main function that is assessed in anatomy textbooks is its role to make femur do external rotation. In addition to external rotation, it also plays role in abduction and stabilization of hip joint. The way the anatomy textbooks we examined assess the function of piriformis muscle is shown in (Table 1). It was observed that not all functions of the muscle were assessed in all of the textbooks, and the changes in femur according to its position were not assessed even the same functions were stated. Also, there are textbooks that use different terminology such as "supination to femur "and that show external rotation in the second place. 


\section{The Function of Piriformis Muscle in Terms of Piriformis Syndrome}

The emergence of symptoms in piriformis syndrome may occur during the contraction of the muscle (hip extension, abduction, and external rotation) or the movements that bring the muscle to the longest position (hip flexion, adduction, internal rotation) [32]. When compared to healthy individuals, the walking of an individual with piriformis syndrome, it is observed that there is less maximum internal rotation and maximum external rotation movements and less normal joint movements in the sagittal plane [32]. The presence of increased hip internal rotation and adduction in some of the cases with piriformis syndrome suggest that piriformis muscle works in a stretched position following exposure to high eccentric force affiliated with weak agonist muscles and causes nerve compression. The symptoms were observed to decrease following the interferences to increase force of hip abduction and external rotation [13]. While the test is performed with resistive external rotation on the hip close to extension, the muscle is stretched in internal rotation. It gets stretched with the external hip rotation in knee flexion over $90^{\circ}[17,22]$. The stretching position involves getting into external rotation with hip flexion while the knee is in flexion [22]. In a study that examines piriformis muscle in its longest position, it was observed that putting hip into $115^{\circ}-120^{\circ}$ flexion, $30^{\circ}-40^{\circ}$ external rotation and $25^{\circ}-30^{\circ}$ adduction increased the extension of muscle by $30-40 \%$ compared to conventional stretching movements [33].

\section{Conclusion}

The obtained information shows that piriformis muscle has functions such as providing abduction in hip flexion, internal rotation and triggering extension along with its main function of providing femur's external rotation while the hip is in extension. In addition to that, considering its role in pelvis lateral tilt and posterior tilt and the fact that it helps provide stabilization of both sacroiliac and hip joint show that it is one of the posture muscles and that it might play an active role during tasks of walking, climbing up and down a ladder, climbing up a hill. We hope that the information about these functions of the muscle will help explaining many pathologies related with the hip, especially the piriformis syndrome, making the differential diagnosis, and choosing the most proper position of the hip for muscle test and muscle related treatments. In this regard, we argue that all functions of piriformis muscle should be assessed in textbooks of fundamental anatomy education. We also think that the terminology used in these textbooks should be standardized in order to make it easier to comprehend its function. Furthermore, advanced studies should be performed for defining the functions of piriformis muscle in clinical context.

\section{References}

1. Snijders CJ, Hermans PF, Kleinrensink GJ (2006) Functional aspects of cross-legged sitting with special attention to piriformis muscles and sacroiliac joints. Clin Biomech (Bristol, Avon) 21(2): 116-121.

2. Standring S (2016) Gray's Anatomy, The Anatomical Basis of Clinical Practise (41 ${ }^{\text {st }}$ Edn.)., Elsevier Ltd.

3. Dilekçi E (2018) PiRiFORMiS SENDROMU: BiR OLGU SUNUMU. Kırıkkale Üniversitesi Tıp Fakültesi Dergisi.

4. Hicks BL, Lam JC, Varacallo M (2021) Piriformis Syndrome. StatPearls Publishing, StatPearls. Treasure Island (FL).

5. Mesci N, Geler Külcü D (2017) Piriformis Syndrome. 57: 172-175.

6. Keith L Moore, Arthur F Dalley, Agur A (2017) Clinically Oriented Anatomy ( $8^{\text {th }}$ Edn.)., Lippincott Williams and Wilkins, Philadelphia PA.

7. Yıldırım M (2017) Sistematik Anatomi (2nd Edn.)., Nobel Tıp Kitapevleri, İstanbul.

8. Brenner E, Tripoli M, Scavo E, Cordova A (2019) Case report: Absence of the right piriformis muscle in a woman. Surg Radiol Anat 41: 845-848.

9. Develi S, Yıldırım A, Yalçın B, Yazar F (2017) Aksesuar musculus piriformis. Cukurova Medical Journal (Çukurova Üniversitesi Tıp Fakültesi Dergisi) 42: 182-182

10. Fahrioglu SL, Koc T, Kurtoglu Z, Ilgi NS (2017) Unusual accessory piriformis muscle: A case report. Journal of the Anatomical Society of India 66: S19-S21.

11. Sen A, Rajesh S (2011) Accessory piriformis muscle: An easily identifiable cause of piriformis syndrome on magnetic resonance imaging. Neurol India 59(5): 769-771.

12. Natsis K, Totlis T, Konstantinidis GA, Paraskevas G, Piagkou M, et al. (2014) Anatomical variations between the sciatic nerve and the piriformis muscle: A contribution to surgical anatomy in piriformis syndrome. Surgical and Radiologic Anatomy 36(3): 273-280.

13. Tonley JC, Yun SM, Kochevar RJ, Dye JA, Farrokhi S, et al. (2010) Treatment of an individual with piriformis syndrome focusing on hip muscle strengthening and movement reeducation: A case report. J Orthop Sports Phys Ther 40(2): 103-111.

14. Hashemirad F, Karimi N, Keshavarz R (2016) The effect of Kinesio taping technique on trigger points of the piriformis muscle. Journal of Bodywork and Movement Therapies 20(4): 807-814.

15. Chaitow L, DeLany J (2011) The hip. In: Chaitow L, DeLany J (Eds.). Clinical Application of Neuromuscular Techniques, Volume 2. Churchill Livingstone, Oxford, pp. 391-445.

16. Chang C, Jeno SH, Varacallo M (2021) Anatomy, Bony Pelvis and Lower Limb, Piriformis Muscle. StatPearls. Treasure Island (FL): StatPearls Publishing.

17. Michel F, Decavel P, Toussirot E, Tatu L, Aleton E, et al. (2013) The piriformis muscle syndrome: An exploration of anatomical context, pathophysiological hypotheses, and diagnostic criteria. Ann Phys Rehabil Med 56(4): 300-311.

18. Garten H (2013) M piriformis. In: Garten H (Edt.)., The Muscle Test Handbook. Churchill Livingstone, pp. 174-177.

19. Pressel T, Lengsfeld M (1998) Functions of hip joint muscles. Med Eng Phys 20(1): 50-56.

20. Giphart JE, Stull JD, Laprade RF, Wahoff MS, Philippon MJ (2012) Recruitment and activity of the pectineus and piriformis muscles during hip rehabilitation exercises: An electromyography study. Am J Sports Med 40(7): 1654-1663 
21. Catelli DS, Bedo BLS, Beaule PE, Lamontagne M (2021) Pre- and postoperative in silico biomechanics in individuals with cam morphology during stair tasks. Clin Biomech (Bristol, Avon) 86: 105387.

22. Neumann D (2009) Kinesiology of the Musculoskeletal System Foundations for Rehabilitation ( $2^{\text {nd }} E d n$.)., Mosby Elsevier.

23. Ekşioğlu MF, Açar Hi, Tekdemir ijTD (2011) Kalça ekleminin fonksiyonel anatomisi. 10: 32-37.

24. Eyüboğlu F, Sayaca Ç, Çalik M, Korkem D, Tascilar LN, et al. (2020) Kinesiology of the hip. In: Angin S, Şimşek IE (Eds.)., Comparative Kinesiology of the Human Body. Academic Press, pp. 375-392.

25. Hallin RP (1983) Sciatic pain and the piriformis muscle. Postgrad Med $74(2): 69-72$

26. Alexander N, Schwameder H (2016) Effect of sloped walking on lower limb muscle forces. Gait Posture 47: 62-67.

27. Key J (2010) Classification of muscles. In: Key J (Edt.)., Back Pain - A Movement Problem. Churchill Livingstone, Edinburgh, pp. 55-71.

\section{ISSN: 2574-1241}

DOI: 10.26717/BJSTR.2021.38.006110

Hüseyin Avni Balcıoğlu. Biomed J Sci \& Tech Res

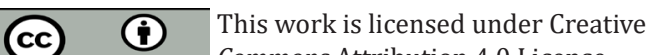

Submission Link: https://biomedres.us/submit-manuscript.php
28. Chung KW, Chung HM, Halliday NL (2017) BRS Gross Anatomi ( $8^{\text {th }}$ Edn.)., İstanbul Tıp Kitapevi, İstanbul.

29. Ozan H (2014) Ozan Anatomi (3 ${ }^{\text {rd }}$ Edn.)., Klinisyen tıp kitabevleri, Ankara.

30. Snell RS (2011) Clinical Anatomy by Regions. Lippincott Williams \& Wilkins.

31. Hansen JT (2014) Netter's Clinical Anatomy.

32. Ismail ET, Abbas T, Javad S, Reza S (2020) Gait analysis of patients with piriformis muscle syndrome compared to healthy controls. Musculoskelet Sci Pract 48: 102165.

33. Gulledge BM, Marcellin Little DJ, Levine D, Tillman L, Harrysson OL, et al. (2014) Comparison of two stretching methods and optimization of stretching protocol for the piriformis muscle. Med Eng Phys 36(2): 212218.

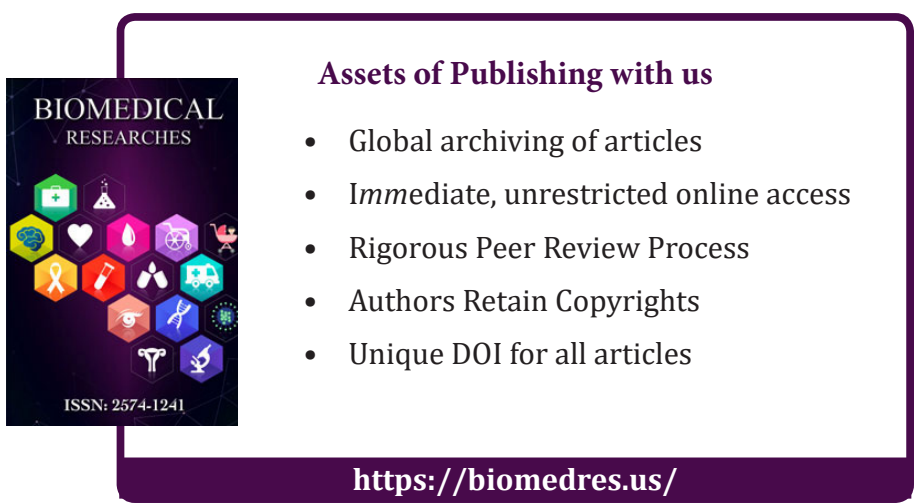

